\title{
Is zinc a limiting nutrient in the diets of rural pregnant Malawian women?
}

\author{
Janet-Marie Huddle ${ }^{1}$, Rosalind S. Gibson ${ }^{2 *}$ and Timothy R. Cullinan ${ }^{3}$ \\ ${ }^{1}$ Division of Applied Human Nutrition, University of Guelph, Guelph, Ontario N1G 2W1, Canada \\ ${ }^{2}$ Department of Human Nutrition, University of Otago, PO Box 56, Dunedin, New Zealand \\ ${ }^{3}$ Department of Community Health, College of Medicine, University of Malawi, Blantyre, Malawi
}

(Received 31 January 1997-Revised 29 September 1997-Accepted 14 October 1997)

\begin{abstract}
Pregnant women consuming plant-based diets are at risk of $\mathrm{Zn}$ deficiency; $\mathrm{Zn}$ requirements for fetal growth and maternal tissue accretion are high. Therefore we have studied, at 24 and 33 weeks gestation, the $\mathrm{Zn}$ status of eighty-seven pregnant rural Malawian women (mean age 22.7 years) who consume maize-based diets, using anthropometry, dietary intake data, plasma and hair $\mathrm{Zn}$ concentrations, and infection status via serum $\mathrm{C}$-reactive protein, leucocyte count, and malaria blood smear. Of the women, $12 \%$ were stunted (height-for-age $\mathrm{Z}$ score $<-2 \mathrm{SD}$ ) and $20 \%$ lost weight over the 9 -week period; weight gain averaged $0.13 \mathrm{~kg} /$ week. Mean plasma $\mathrm{Zn}$ concentration declined significantly from 24 to 33 weeks (7.9 (SD 2.2) v. 6.6 (SD 2.0) $\mu \mathrm{mol} / \mathrm{l}$; $P<0.0003$ ). Both plasma and hair $\mathrm{Zn}$ values were very low; nearly $50 \%$ of the women had both plasma and hair $\mathrm{Zn}$ values below acceptable cut-off values. No significant differences in biochemical $\mathrm{Zn}$ indices existed between those who tested positive and negative for infection. Cereals (mainly maize) provided more than two-thirds of mean energy intake compared with less than $5 \%$ from flesh foods. As a result about $60 \%$ of the subjects had dietary phytate : $\mathrm{Zn}$ molar ratios greater than 15 , and more than $35 \%$ had inadequate $\mathrm{Zn}$ intakes based on probability estimates and WHO basal requirements. Biochemical evidence of $\mathrm{Zn}$ deficiency was attributed in part to low intakes of poorly available $\mathrm{Zn}$. The anthropometric, biochemical, and dietary data together indicate that $\mathrm{Zn}$ deficiency may be a factor limiting pregnancy outcome in rural Malawian women.
\end{abstract}

\section{Zinc: Pregnancy: Malawi}

In developing countries many women are pregnant and lactating for a large part of their reproductive lives. These stresses of frequent reproduction and lactation have a detrimental effect on maternal nutritional status, especially if maternal dietary intakes are inadequate to meet nutrient needs (Merchant et al. 1990a,b). Requirements for $\mathrm{Zn}$ are especially high during pregnancy because $\mathrm{Zn}$ is essential for growth and development of the fetus and maternal tissue accretion. Despite the existence of several adaptive mechanisms during pregnancy to help meet these increased demands for $\mathrm{Zn}$ (Swanson \& King, 1987), pregnant women in rural Southern Malawi may be particularly at risk of $\mathrm{Zn}$ deficiency because their diets are predominately cereal-based; intakes of flesh food, a rich source of readily available $\mathrm{Zn}$, are generally low (Ferguson et al. 1995). These rural Malawian diets have phytate: $\mathrm{Zn}$ (Phy: $\mathrm{Zn}$ ) molar ratios at levels known to inhibit $\mathrm{Zn}$ absorption (Oberleas \& Harland, 1981; Bindra et al. 1986; Ferguson et al. 1989a). In addition, several non-nutritional factors such as increased losses of $\mathrm{Zn}$ via sweat, skin, and parasitic infections, and chronic haemolysis induced by malaria and schistosomiasis may all exacerbate the risk of $\mathrm{Zn}$ deficiency (Solomons, 1981).

Results of an earlier dietary study of pregnant Malawian women revealed that most of the women (approximately $95 \%$ ) were at risk of inadequate intakes of dietary $\mathrm{Zn}$ (Ferguson et al. 1995). Although no biochemical indices of Zn status were included in this earlier study, such dietary inadequacies are a cause for concern as the limited diet

\footnotetext{
Abbreviations: AMA, arm muscle area; FAO/WHO/UNU, Food and Agriculture Organization/World Health Organization/United Nations University; MUAC, mid upper arm circumference; NHANES, National Health and Nutrition Examination Survey; Phy : Zn, phytate: zinc; SES, socioeconomic status. * Corresponding author: Professor R. S. Gibson, fax + 643479 7958, email Rosalind.Gibson@stonebow.otago.ac.nz
} 
could have a detrimental impact on both maternal health and pregnancy outcome. In some but not all human studies, suboptimal $\mathrm{Zn}$ nutriture during pregnancy has been associated with pregnancy complications, low birth weight, and congenital anomalies (Apgar, 1985, 1992; Swanson \& King, 1987; Valdes-Ramos, 1992; Tamura \& Goldenberg, 1996). Therefore to confirm whether $\mathrm{Zn}$ is a limiting nutrient in the diets of pregnant Malawian women, we have examined the relationship between anthropometric, biochemical and dietary indices of $\mathrm{Zn}$ status in a selected group of rural Malawian women at 24 and 33 weeks gestation.

\section{Methods}

\section{Participants}

Women in this study were all attending prenatal clinics held at Jalasi Health Centre, a rural health centre located in Traditional Authority (TA) Jalasi, Mangochi District, Southern Malawi. Women aged $14-45$ years and less than 24 weeks gestation based on last date of menstrual period and/or fundal height, with no history of Caesarean section and an initial haemoglobin $>80 \mathrm{~g} / \mathrm{l}$, were eligible to participate. The study protocol was approved by the Human Ethics Committee, University of Guelph, Canada and the Health Sciences Research Committee, University of Malawi. Verbal consent was obtained from the traditional authorities in the villages surrounding the health centre and from the participants after the nature of the study had been fully explained to them. The study extended over an 8month period from November 1993 to June 1994.

Between November 1993 and February 1994, a convenience sample of eighty-seven women (mean age 22.7 (SD 5.1 ) years) was recruited at 23.7 (SD 2.2) weeks gestation based on last date of menstrual period and/or fundal height. Data on general health, demographic and socio-economic status, reproductive history, previous lactation behaviour, and family characteristics were collected by personal interviews and repeated observations in the homes of the participants using a pre-tested questionnaire. From these data, a socio-economic status (SES) index was developed based on the model of Kirksey et al. (1994) which incorporated the following categories: (a) house quality (maximum score $=3$ ): thatched roof $=0$, tin roof $=1$, mud walls $=0$, sunbaked bricks $=0$, fired bricks $=1$, windows $=1$, no windows $=0$; (b) sanitation (maximum score $=2$ ): no latrine $=0$, latrine $=1$, shared latrine $=0$, private latrine $=1$; (c) water source (maximum score $=3$ ): river $=0$, uncovered well $=1$, covered well $=2$, tap or borehole $=3$; (d) household size (maximum score $=2$ ): two or fewer people $=1$, three to seven people $=2$, eight or more people $=1$; (e) occupation (maximum score $=2$ ) (head of household): estate worker or teacher $=2$, business or nonfarmer $=1$, farmer $=0$; and (f) schooling (maximum score $=2$ ): none $=0,4$ years or less $=1$, more than 4 years $=2$. This allowed the definition of four SES categories, based on a total possible maximum score of 14 .

\section{Anthropometric assessment}

Anthropometric measurements of weight, standing height, mid-upper arm circumference (MUAC) and skinfold thicknesses were taken on the women at 23.7 (SD 2.2) and 32.9 (SD 1.7) weeks gestation by the same anthropometrist (with the exception of body weight) to eliminate inter-examiner error. All measurements were performed in the morning in duplicate using standardized techniques (Lohman et al. 1988) with women wearing light clothing without shoes. Weight was measured to the nearest 0.5 pound using a weighing scale (Health-o-meter, Wilder Medical, Bridgeview, IL, USA) levelled and calibrated daily and height with a modified tape-measure (Microtoise, CMS Weighing Equipment Ltd, London, UK) fixed to the wall of the health centre. Elbow breadth was measured on the right arm with a sliding caliper (Bicondylar Holtain, Holtain Ltd, Crymmych, Dyfed, UK) and MUAC at the midpoint of the upper right arm with a fibreglass insertion tape (Ross Lab, Columbus, OH, USA). Triceps, biceps, subscapular, supra-iliac and medial thigh were measured on the right side using precision calipers (Lange, Cambridge Scientific Industries Inc., Cambridge, MA, USA); the location of the measurement sites was taken from Lohman et al. (1988).

Maternal weight gain was calculated as the difference between weights at 24 and 33 weeks gestation. Rate of weight gain per week was determined by dividing individual weight gain by the number of weeks between measurements. $Z$ scores for maternal height-for-age, elbow breadth, MUAC, arm muscle area (AMA), arm fat area, arm fat indices, triceps and sum of subscapular and triceps skinfolds were calculated using National Health and Nutrition Examination Survey (NHANES) I and II reference data for black people (Frisancho, 1990). These Z-scores were compared with those for non-pregnant women because no reference data exist for pregnant women.

\section{Dietary assessment}

Women received some initial training on our modified interactive $24 \mathrm{~h}$ recall procedure by trained Yao-speaking research assistants. The interactive $24 \mathrm{~h}$ recall method had been validated earlier in a group of sixty pregnant women living in three villages in the same Traditional Authority district in Southern Malawi-TA Jalasi, Mangochi District (Ferguson et al. 1995). In the validation study, dietary intakes of the repeated interactive $24 \mathrm{~h}$ recalls were compared with those of weighed food records collected on the same $2 \mathrm{~d}$ of food intake. There were no significant differences in median daily intakes of $\mathrm{Ca}, \mathrm{Fe}, \mathrm{Zn}$ and $\mathrm{Mn}$ between the two methods. In addition, when intakes (per $\mathrm{MJ}$ and as a percentage of energy from food groups) were classified into tertiles, agreement was considered satisfactory. Moreover, the proportions of women (\%) with trace mineral intakes at risk of inadequacy based on the probability approach, were very similar for the two methods. Dietary intake results from the recalls were also compared with weighed records collected from the sixty women for $2 \mathrm{~d} 1-2$ weeks before and after the weighed record data collection period. Results indicated that the weighed records did not significantly influence the sameday recalls because they were not consistently different from those collected during the non-weighed periods. 
Three non-consecutive, interactive, $24 \mathrm{~h}$ recalls were conducted on each woman at approximately 24 weeks gestational age, on Sunday, Tuesday and Thursday or Monday, Wednesday and Friday in their own homes. The interactive $24 \mathrm{~h}$ recall method incorporates the use of plates and picture charts to aid respondents in portion size estimation and recall. Each woman was given a plate, and asked to eat her food separately from this plate to aid visual recall of portion size. Picture charts depicting commonly consumed food items were used as a checklist on the day the food was consumed and compared with the recall on the following day. Any discrepancies were queried and resolved.

To aid in the estimation of portion size, samples of commonly consumed foods were prepared daily using local cooking methods. The women indicated how much of these prepared food items they had consumed during the previous $24 \mathrm{~h}$ using their own plates and utensils and the research assistant weighed and recorded the amount. Scales used were accurate to within $1 \mathrm{~g}$ ( $2 \mathrm{~kg}$ maximum weight; Hanson digital kitchen scales, Arden Forest, Warwickshire, UK), and were calibrated daily by weighing an item of known weight. Meat weights were estimated by weighing an equivalent volume of stiff maize porridge (nsima), and converting to meat weight using the density of the two foods. Fruit, pumpkin and sugar-cane weights were estimated by using household food items of similar size.

Intakes of energy, selected nutrients, dietary fibre (as NSP) and phytate (per d, per MJ, and per food group), Phy: Zn molar ratios and intakes of major food groups $(\mathrm{g} / \mathrm{d})$ were calculated from the coded dietary recall data using a previously compiled Malawian food composition table based on analysed and literature values (Ferguson et al. 1988, $1989 a, b)$. Energy and protein intakes were adjusted for digestibility by 0.95 and 0.85 respectively (Food and Agriculture Organization/World Health Organization/ United Nations University (FAO/WHO/UNU), 1985).

Mean estimated $\mathrm{Zn}$ availability was calculated from the mean Phy: $\mathrm{Zn}$ molar ratios of the diets for each subject; absorption was estimated as $15 \%$ if molar ratios of Phy: $\mathrm{Zn}$ were between 15 and 30 and $30 \%$ if Phy: $\mathrm{Zn}$ ratios were $<15$ (WHO, 1996). The $\mathrm{Ca}$ and animal protein contents of the diets of these women were too low to have an impact on $\mathrm{Zn}$ absorption and hence were not taken into account in the calculation of available dietary $\mathrm{Zn}$. None of the women received $\mathrm{Fe}$ or $\mathrm{Zn}$ supplements during pregnancy.

The adequacy of intakes of energy was evaluated as the percentage of women with intakes below two-thirds of the FAO/WHO/UNU (1985) recommendation for energy whereas those for protein and $\mathrm{Zn}$ were evaluated using the probability approach based on the FAO/WHO/UNU (1985) recommendations for protein and the WHO (1996) basal and normative requirements for $\mathrm{Zn}$.

\section{Biochemical assessment}

At the prenatal clinics non-fasting, morning venepuncture peripheral blood samples were collected from participants at 23.7 (SD 2.2) and 32.9 (SD 1.7) weeks gestation into trace element-free lithium-heparinized and non-heparinized tubes
(Monovette Sarstedt, St Laurent, Quebec, Canada) with the women in the sitting position. Blood samples were placed in a cooler as soon as possible after collection.

Portions of anticoagulated whole blood were used for total leucocyte count using a Unopette collection system (Becton-Dickinson, Rutherford, NJ, USA) and one examiner, and thick blood smears stained with Giemsa stain $(40 \mathrm{~g} / \mathrm{l})$ for malaria screening. For the latter, parasites and leucocytes were counted in the same fields until 300 leucocytes or 500 parasites were recorded. The remaining heparinized blood was separated within $3 \mathrm{~h}$ of collection using trace-element-free techniques into trace-element-free polypropylene vials before being frozen immediately at $-10^{\circ}$ and later at $-20^{\circ}$.

For the $\mathrm{Zn}$ analyses, plasma was weighed into glass ignition tubes (Pyrex Corning $10 \times 70 \mathrm{~mm}$ ), frozen, and then freeze-dried (Model FD-6-UP, FTS Systems Inc., Stone Ridge, NY, USA). Samples were then heated by ramping to $480^{\circ}$, ashed overnight in a muffle furnace (51894, Lindberg, Watertown, WI, USA) and then reconstituted with $1.25 \mathrm{M}-\mathrm{HNO}_{3}$ (Ultrex II Ultrapure, JT Baker Chemical Co., Phillipsburg, NJ, USA). After diluting samples 1:5 with distilled, deionized water, they were analysed by flame atomic absorption spectrophotometry (Varian SpectraAA-30, Varian Techtron Ltd, Georgetown, Ontario, Canada) using a modification of the method of Veillon et al. (1985).

The accuracy of the plasma $\mathrm{Zn}$ method was determined by daily assay of a bovine reference serum (National Institute of Standards and Technology, Standard Reference Material 1598). The mean value for eight samples was 13.8 (SD 1.7) $\mu \mathrm{mol} / 1$ (CV, $12 \%$ ) compared with the certified value of 13.6 (SD 0.9) $\mu \mathrm{mol} / 1$. Pooled serum samples $(n 5)$ were assayed to assess precision of the method between assays. The mean value was 15.2 (SD 1.7) $\mu \mathrm{mol} / \mathrm{l}(\mathrm{CV}$, $11 \%$ ). The CV of duplicate samples $(n 21)$ used to assess within-run precision was $6 \%$.

Serum albumin and C-reactive protein were assessed via turbimetric methods (Behring Turbitimer System, Somerville, NJ, USA). Measured $v$. certified values for quality control sera for albumin (N/T Protein control SY/M Medium; Behring Diagnostics, Somerville, NJ, USA) ( $n$ 9) and C-reactive protein (Behring Diagnostics) $(n 9)$ respectively were: 4.0 (SD 1.6, CV $4 \%$ ) v. 4.1-5.6 g/l and 20.2 (SD $1.9, \mathrm{CV} 9 \%$ ) v. 18.4-25.0 mg/1. Inter-assay precision values for serum albumin and C-reactive protein, assessed via analysis of a pooled serum were $7 \%(n 7)$ and $9 \%$ (n 26) respectively.

Maternal hair samples for $\mathrm{Zn}$ analysis were obtained from the occipital region of the scalp using stainless steel scissors at 23.7 and 32.9 weeks gestation; only the proximal $10-15 \mathrm{~mm}$ of the hair strands were used for analysis. Hair samples were checked for nits and lice before washing with a non-ionic detergent (Actinox) using a standard procedure (Gibson \& DeWolfe, 1979). After drying the washed hair samples, they were packaged in sealed polyethylene bags, and later analysed by instrumental neutron activation. A pooled hair sample was used to assess inter-assay precision. Mean $\mathrm{Zn}$ concentration was 1.43 (SD 0.21 ) $\mu \mathrm{mol} / \mathrm{g}$ (CV 15\%); CV for the repeated analysis of the same sample $(n 20)$ was $6 \%$. 


\section{Statistical analysis}

All data were tested for normality using the ShapiroWilkes test. Paired $t$ tests were used to compare normally distributed longitudinal data. The non-parameteric Wilcoxon signed rank test was used to determine significant difference in non-normally distributed paired data. For consistency, all dietary intakes are reported as median intakes, although energy, protein and $\mathrm{Zn}$ intakes were normally distributed at 24 weeks gestation.

Pearson correlation coefficients were calculated for correlation analysis. Multiple linear regression was used to investigate relationships and interactions between independent variables and plasma and hair $\mathrm{Zn}$ concentrations. All statistical tests were performed using the Statistical Analysis System (SAS version 6.09, 1982, and PC SAS for Windows version 6.11.NC; SAS Institute Inc., Cary, NC, USA).

\section{Results}

\section{Characteristics of study participants}

The pregnant women of this study were characterized by having little or no formal education; they were primarily subsistence farmers living in houses made of sundried brick with thatched roofs, and using a shared latrine. The ratio adult females : adult males per household was 1.4 , with the mean number of people per household equal to 3.5 (SD 1.8). Data from the SES index revealed that most of the women (i.e. $71 \% ; n$ 64) were classified into the two lowest SAS categories (i.e. equivalent to SES scores of 1-3 and 47), $22 \%(n 19)$ in the next highest category (i.e. SES score $8-10)$, and only $5 \%(n 4)$ in the highest SES category (i.e. score 11-14).

Gravida ranged from one to eleven in the study group. Of the women, $32 \%$ ( $n$ 28) were primagravid, $47 \%$ ( $n$ 41) were gravida two to four, and $21 \%$ ( $n$ 18) were gravida five or more. Women of gravida two or more averaged 3.5 live births and 1.0 dead children compared with the national average in Malawi for women aged 15-49 years of 3.48 births, and 0.93 dead children (National Statistical Office, Malawi, 1994). Of the multiparous women, $93 \%$ had a child born in the previous 5 years; $65 \%$ had given birth in the previous 3 years, and $3 \%$ in the last year. According to the recent national survey, less than $12 \%$ of rural women in Malawi use any form of birth control (National Statistical Office, Malawi, 1994).

\section{Anthropometric assessment}

Mean anthropometric measurements, associated indices and Z-scores are presented in Table 1 . Not surprisingly, weight at 24 weeks correlated with weight at 33 weeks $(r 0.96 ; P<0.0001$ ). Weight gain averaged 1.3 (SD 1.7) $\mathrm{kg}$ for the entire period between 24 and 33 weeks, yielding a rate of gain of 0.13 (SD 0.2$) \mathrm{kg} /$ week. Some women ( $20 \%)$ (n 17) lost weight during this time, and $8 \%(n 7)$ showed no weight gain. When women were classified as 'failure to gain' ( $n$ 24) v. those who gained weight ( $n$ 63), there were no significant differences between the two groups at 24 weeks. However, at 33 weeks, the gainers had significantly higher leucocyte counts $\left(7.3\right.$ v. $\left.5.7 \times 10^{9} / 1\right)$. Not surprisingly, they also showed lower reductions in MUAC, subscapular and supra-iliac skinfolds and AMA as well as lower plasma $\mathrm{Zn}$ concentrations (5.9 $v .6 .9 \mu \mathrm{mol} / \mathrm{l}$; $P=0.04)$; differences in age, height and weight were not significant.

Mean Z-scores for all anthropometric indices were lower than the corresponding mean NHANES I and II reference values for black people except for AMA. The lowest mean Z-score was found for maternal height, with $12.5 \%$ of the women with height-for-age Z-score $<-2$ SD the value considered indicative of stunting. Anthropometric variables of MUAC and all skinfolds were significantly correlated with each other $(P=0.0001)$ but not with any of the biochemical indices of protein, $\mathrm{Fe}$ or $\mathrm{Zn}$ status.

\section{Dietary assessment}

Intakes of energy and selected nutrients and antinutrients (per d and per MJ) at 24 and 33 weeks are presented in Table 2. No significant differences between intakes (per d) at 24 and 33 weeks were found, although intakes per MJ for $\mathrm{Fe}$ and $\mathrm{Cu}$ were different $(P<0 \cdot 01$; Table 2$)$. Intakes of

Table 1. Mean anthropometric growth measurements, indices, and Z-scores for eighty-seven pregnant rural Malawian women

(Mean values, Z-scores and standard deviations)

\begin{tabular}{lcclll}
\hline & $\begin{array}{c}\text { Date } \\
\text { (weeks) }\end{array}$ & Mean & SD & Z-score & SD \\
\hline Fundal height (weeks) & 24 & 23.7 & 2.2 & & \\
Weight (kg) & 33 & 32.9 & 1.7 & & \\
& 24 & 53.7 & 7.2 & & \\
Height (m) & 33 & 55.0 & 7.2 & & \\
Elbow breadth (mm) & 24 & 1.54 & 0.058 & -1.4 & 0.9 \\
Mid upper arm circumference (cm) & 24 & 60 & 3 & -0.60 & 0.7 \\
& 24 & 26.7 & 2.1 & -0.41 & 0.4 \\
Arm muscle area (cm ${ }^{2}$ ) & 33 & 26.2 & 2.1 & -0.52 & 0.4 \\
& 24 & 38.9 & 6.4 & 0.46 & 0.7 \\
Arm fat area (cm $\left.{ }^{2}\right)$ & 33 & 39.0 & 5.7 & 0.46 & 0.6 \\
& 24 & 18.2 & 5.4 & -0.56 & 0.4 \\
Arm fat index (\% fat) & 33 & 15.9 & 4.9 & -0.70 & 0.3 \\
& 24 & 31.6 & 6.4 & -0.57 & 0.6 \\
& 33 & 28.7 & 6.0 & -0.84 & 0.5 \\
\hline
\end{tabular}


Table 2. Intakes of energy and seiected nutrients and antinutrients of Malawian women at 24 weeks and 33 weeks of pregnancy

(Median values, with first and third quartiles in parentheses)

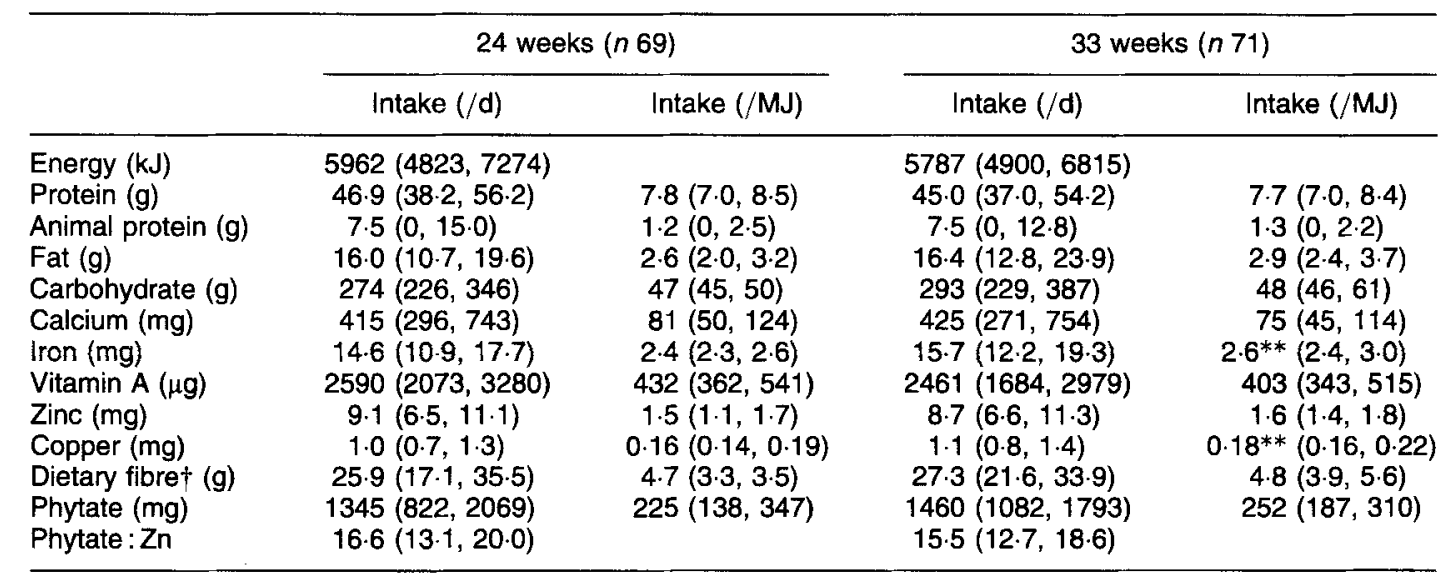

Median values were significantly different from those for 24 weeks, ** $P<0.01$.

+ Expressed as NSP.

macronutrients were correlated with energy intake at both 24 and 33 weeks. Intakes of energy and macronutrients were not correlated between 24 and 33 weeks. Dietary $\mathrm{Zn}$ intakes were correlated $(P<0.0001)$ at 24 weeks gestation with intakes of animal protein $(r 0.53)$ and energy $(r 0.70)$ and also at 33 weeks gestation (animal protein: $r 0.60$; energy: $r 0.67)$. The high mean daily intakes of phytate and dietary fibre (as NSP), and the relatively high Phy: Zn molar ratios (range 6.3-27.9 at 24 weeks, 5.1-26.3 at 33 weeks) compared with the very low median intakes of animal protein at both 24 and 33 weeks gestation should be noted. Of the women, $62 \%$ at 24 weeks and $58 \%$ at 33 weeks had Phy: $\mathrm{Zn}$ molar ratios greater than 15 . The estimated availability of $\mathrm{Zn}$ was $21 \%$ on average (i.e. moderate).

The major food sources of energy, protein and $\mathrm{Zn}$ are shown in Table 3. Grains (primarily maize) provided more than two-thirds of the mean intake of energy, protein and $\mathrm{Zn}$ at 24 and 33 weeks gestation. Less than $5 \%$ of energy intake was provided by the meat, poultry, fish food group, although this food group contributed $18-19 \%$ of intake for protein and $21-23 \%$ for $\mathrm{Zn}$. Fish constituted more than $85 \%$ of the 'animal' protein; dry fish was consumed on $23-31 \%$ of days and fresh fish on $6-8 \%$ of days; chicken and goat combined were eaten only on $3-4 \%$ of recall days.
Intakes of energy, protein, fat, and $\mathrm{Zn}$ did not correlate significantly with weight change $(\mathrm{kg})$ or rate of weight change (kg/week) between 24 and 33 weeks. Furthermore, there was no demonstrable relationship between energy and protein intake and rate of weight gain, when controlling for infection and interactions between variables.

The percentage of women receiving less than two-thirds of the recommended intake for energy (adjusted) (FAO/WHO/UNU, 1985) at 24 and 33 weeks were 91 and $92 \%$ respectively. When probability analysis was used, 38 and $35 \%$ of women were considered at risk of inadequate intakes of $\mathrm{Zn}$ based on the WHO (1996) basal requirement estimates at 24 and 33 weeks gestation respectively, assuming $21 \%$ absorption. These prevalence estimates rose to 57 and $56 \%$ when the normative requirement estimates were used. The percentage of women at risk of inadequate intakes based on probability analysis was also high for protein (adjusted), ranging from $27 \%$ at 24 weeks to $35 \%$ at 33 weeks gestation.

\section{Biochemical assessment}

Mean plasma $\mathrm{Zn}$ concentration decreased by $16 \%$ between 24 and 33 weeks gestation (Table 4). Of the women, $43 \%$ at 24 weeks and $47 \%$ at 33 weeks had plasma

Table 3. Mean percentages of energy, protein and zinc intakes provided by the major food groups in Malawian women at 24 weeks $(n 69)$ and 33 weeks $(n 71)$ of pregnancy $\dagger$

\begin{tabular}{llcccccc}
\hline & & Grains & Legumes & MPF & Sweets & Vegetables & Fruit \\
\hline Energy & 24 weeks & 78.1 & 5.1 & 4.6 & 5.3 & 3.4 & 2.5 \\
& 33 weeks & 72.3 & 5.5 & 4.4 & $9.0^{* * *}$ & $5.5^{* * *}$ & 2.6 \\
Protein & 24 weeks & 60.2 & 10.6 & 18.8 & 0.7 & 7.7 & $<1$ \\
& 33 weeks & 57.7 & 11.4 & 17.7 & $1.9^{* *}$ & 9.7 & $<1$ \\
Zinc & 24 weeks & 60.0 & 7.2 & 23.0 & $<1$ & 8.3 & $<1$ \\
& 33 weeks & 61.7 & 7.1 & 21.1 & $<1$ & 8.7 & $<1$ \\
\hline
\end{tabular}

MPF, meat (ooat), poultry (chicken) and fish.

Mean values were significantly different from those for 24 weeks, $* * P<0.01$.

$\dagger$ Fats, milk, eggs and miscellaneous categories each contributed less than $1 \%$ of total energy intake. 
Table 4. Hair zinc, plasma zinc and serum albumin concentrations in Malawian women at 24 weeks and 33 weeks of pregnancy

\begin{tabular}{llllll}
\hline & \multicolumn{2}{c}{24 weeks } & & \multicolumn{2}{c}{33 weeks } \\
\cline { 2 - 3 } \cline { 5 - 6 } & Mean & SD & & Mean & SD \\
\hline Hair zinc $(\mu \mathrm{mol} / \mathrm{g})$ & $2.0(n 85)$ & 0.7 & & $2.0(n 84)$ & 0.9 \\
Plasma zinc $(\mu \mathrm{mol} / \mathrm{l})$ & $7.9(n 65)$ & 2.2 & & $6.6 * * *(n 72)$ & 2.0 \\
Serum albumin $(\mathrm{g} / \mathrm{l})$ & 32 & 6 & & 30 & 34 \\
\hline
\end{tabular}

Mean value was significantly different from that for 24 weeks, $* * * P<0.0003$.

$\mathrm{Zn}$ values below the cut-off values specific for gestational age (i.e. $<7.1 \mu \mathrm{mol} / 1$ at 24 weeks and $<6.5 \mu \mathrm{mol} / 1$ at 33 weeks; Hambidge et al. 1983). Serum albumin values (Table 4) were only just below the reference mean ( $33 \mathrm{~g} / 1$ at 24 weeks; $32 \mathrm{~g} / 1$ at 33 weeks; Lockitch, 1993) and were positively correlated with plasma $\mathrm{Zn}(r 0.35 ; P=0.0001)$, but not protein intake. Mean hair Zn concentrations are also shown in Table 4. Using a cut-off value of $1.68 \mu \mathrm{mol} / \mathrm{g}, 32$ and $42 \%$ of women had hair $\mathrm{Zn}$ concentrations at 24 and 33 weeks respectively below this value. There was no significant difference in the hair $\mathrm{Zn}$ concentrations between the two time periods. No significant correlations existed between plasma and hair $\mathrm{Zn}$ concentrations or among plasma and/or hair $\mathrm{Zn}$ concentrations with age, SES, birth interval, or dietary $\mathrm{Zn}$ intakes.

Of the three indices of infection assessed in the present study, the proportions of subjects who tested positive for infection at 24 and 33 weeks respectively were: $2.7 \%$ on both occasions for leucocyte count $>11 \times 10^{9} / 1 ; 11$ and $15 \%$ for serum C-reactive protein $>15 \mathrm{mg} / 1$ (Watts et al. 1991) and 26 and $10.8 \%$ for malaria. Plasma $\mathrm{Zn}$ was not correlated with any single measure of infection. Moreover, there was no significant difference between plasma $\mathrm{Zn}$ or serum albumin concentrations at 24 or 33 weeks gestation in women who tested positive $v$. negative for infection. Plasma $\mathrm{Zn}$ concentration was lower $(P=0.04)$ in those women classified as gainers at 33 weeks.

\section{Discussion}

Our results reveal low levels of poorly available dietary $\mathrm{Zn}$ in the diets of these pregnant women living in rural Southern Malawi. Of the women studied, approximately one-third were at risk of inadequate intakes of $\mathrm{Zn}$ when compared with the WHO basal requirement estimates; this proportion rose to over $50 \%$ when based on the normative requirement estimates (WHO, 1996). These prevalence estimates are nevertheless lower than earlier estimates (i.e. $95 \%$ ) for Malawian pregnant women, attributed to seasonal differences in food consumption patterns between the two studies. The study reported here was conducted in the rainy season when more small fish (fresh and dried) were consumed, fish being a food with a relatively high $\mathrm{Zn}$ content and density. Hence, approximately $60 \%$ of the pregnant women reported here compared with $94 \%$ reported earlier (Ferguson et al. 1995) had Phy: Zn molar ratios greater than 15 , the critical level said to compromise $\mathrm{Zn}$ absorption (Oberleas \& Harland, 1981). The increased consumption of fish also resulted in higher $\mathrm{Ca}$ intakes compared with our earlier Malawian study $(296 \mathrm{mg} / \mathrm{d}$;
Ferguson et al. 1995), although dietary Ca levels were probably still too low to exacerbate any phytate-induced inhibition of $\mathrm{Zn}$ absorption (Davies et al. 1985; Bindra et al. 1986; WHO, 1996). By contrast, average daily intakes of energy, and protein, fat and $\mathrm{Cu}$ per $\mathrm{MJ}$ reported here were all comparable with those documented previously, but intakes of $\mathrm{Fe}$, dietary fibre and phytate per $\mathrm{MJ}$ were higher (Ferguson et al. 1995).

Zn bioavailability must be considered when evaluating the adequacy of dietary $\mathrm{Zn}$ in relation to requirement estimates. In these rural plant-based Malawian diets, with elevated Phy: Zn molar ratios and low intakes of flesh foods, $\mathrm{Zn}$ bioavailability was estimated as $21 \%$. This level corresponds to 'moderate' bioavailability based on the WHO (1996) classification. Hence, for pregnant Malawian women to meet their estimated basal requirement for $\mathrm{Zn}$ (WHO, 1996) for the second trimester of pregnancy, an additional intake of approximately $1.4 \mathrm{mg} \mathrm{Zn} / \mathrm{d}$ is required. This amount is equivalent to an additional daily 0.45 servings of the staple stiff maize porridge (nsima), 0.33 servings of dried fish or 0.69 servings of dried beans. To meet the second and third trimester normative requirements, increases of $5.0 \mathrm{mg} / \mathrm{d}$ ( 3.6 times the given servings) and $6.2 \mathrm{mg} / \mathrm{d}$ ( 4.4 times the given servings) respectively, are required. Such large increases in serving sizes of staple foods, however, are not economically feasible in this population. Therefore, any strategy to alleviate dietary $\mathrm{Zn}$ inadequacies must emphasize ways of improving the bioavailability of $\mathrm{Zn}$ in existing Malawian diets rather than their $\mathrm{Zn}$ content.

Diagnosis of $\mathrm{Zn}$ deficiency is generally based on the existence of several concordant abnormal biochemical indices. In the present study two static biochemical indices of $\mathrm{Zn}$ status, plasma and hair $\mathrm{Zn}$ concentrations, were examined in combination with dietary $\mathrm{Zn}$ indices. Despite the frequent use of plasma $\mathrm{Zn}$ as an index of $\mathrm{Zn}$ status, its interpretation is difficult, especially during pregnancy when levels fall even in the presence of optimal $\mathrm{Zn}$ nutriture (Breskin et al. 1983; Hambidge et al. 1983; Campbell-Brown et al. 1985; Nagra et al. 1988). This decline is attributed to expansion in plasma volume, increased oestrogen levels, and a fall in serum albumin, the main $\mathrm{Zn}$-binding protein (Swanson \& King, 1983).

Tuttle et al. (1985) used measurements of plasma volume and plasma $\mathrm{Zn}$ concentrations during pregnancy to calculate changes in the intravascular mass of $\mathrm{Zn}$. Application of a maximum plasma volume of 3.5 litres to our mean plasma $\mathrm{Zn}$ value at 24 weeks gestation (i.e. $8.0 \mu \mathrm{mol} / \mathrm{l})$ results in a $\mathrm{Zn}$ mass of $26.4 \mu \mathrm{mol} / 1$. To 
maintain this $\mathrm{Zn}$ mass at 33 weeks gestation with plasma $\mathrm{Zn}$ values as low as $6.6 \mu \mathrm{mol} / 1$ (Table 4) necessitates a plasma volume of 4 litres, a value beyond the suggested normal range. Indeed, because of the low weight gain experienced by these Malawian women, expansion of maternal plasma volume was likely to be reduced (Scholl et al. 1992). Hence, the low plasma $\mathrm{Zn}$ concentrations observed here are unlikely to result from changes in plasma volume, but instead from $\mathrm{Zn}$ depletion.

Infection also lowers plasma $\mathrm{Zn}$ concentrations by a redistribution of $\mathrm{Zn}$ from the plasma to the liver mediated by the acute-phase response (Kushner, 1993). However, we found no correlations between the individual indices of infection (i.e. leucocyte count, serum C-reactive protein and malaria) and plasma $\mathrm{Zn}$ concentrations. In addition, we could not demonstrate a significant difference in plasma $\mathrm{Zn}$ concentrations between women classified as infected $v$. non-infected, a finding consistent with that of Brown et al. (1993).

To our knowledge, mean plasma $\mathrm{Zn}$ values reported here at both 24 and 33 weeks gestation (Table 4) are lower than values reported from other developing countries. For example, mean serum $\mathrm{Zn}$ values for Nigerian women during the second trimester were 8.3 (SD 1.5) $\mu \mathrm{mol} / 1$ (Mbofung \& Atinmo, 1987) and 7.4 (SD 2.2) $\mu \mathrm{mol} / 1$ at delivery (Okonofua et al. 1990) compared with 7.9 (SD 2.0) $\mu \mathrm{mol} / 1$ for 166 Zairian women at delivery (Arnaud et al. 1994). In Egypt the mean mid-pregnancy plasma $\mathrm{Zn}$ value was 10.0 (SD 2.1) $\mu \mathrm{mol} / 1$ (Kirksey et al. 1994). Of our Malawian women, $43 \%$ at 24 weeks and $47 \%$ at 33 weeks gestation had plasma $\mathrm{Zn}$ values below the gestational-age specific cut-off values developed by Hambidge et al. (1983).

The biological significance of these low plasma $\mathrm{Zn}$ concentrations in pregnancy is controversial because relationships between maternal plasma $\mathrm{Zn}$ and pregnancy outcome have been so inconsistent, varying with both the stage of gestation and the outcome variable measured (McMichael et al. 1982; Apgar, 1985, 1992; Tamura \& Goldenberg, 1996). Some of these inconsistencies may have arisen because of the failure to account for confounding variables such as smoking (Kuhnert et al. 1988) and BMI (Goldenberg et al. 1995). Although none of the pregnant Malawian women smoked, their mean BMI at 24 weeks gestation was only $22.6(\mathrm{SD} 2 \cdot 1) \mathrm{kg} / \mathrm{m}^{2}$. Such low BMI and plasma $\mathrm{Zn}$ values at this stage of pregnancy are cause for concern. Significant increases in birth weight and head circumference were reported in infants born to Zn-supplemented Afro-American women with BMI below 26.0 and below-average plasma $\mathrm{Zn}$ levels at prenatal enrolment compared with their corresponding placebo controls (Goldenberg et al. 1995). In light of these findings, it seems likely that the high prevalence of very low plasma Zn concentrations concomitant with the low BMI values reported here could have a negative impact on pregnancy outcome. Unfortunately, village deliveries were the custom for most of the Malawian women of this study; less than $25 \%$ of the infants born to the mothers in this study were delivered in the health centre, making data on birth outcome difficult to obtain in this rural setting.
Further support for the existence of suboptimal $\mathrm{Zn}$ status in these pregnant women was provided by the low hair $\mathrm{Zn}$ concentrations; values were approximately $30 \%$ below those reported by others during pregnancy (Sarram et al. 1969; Hambidge \& Droegemueller, 1974; Vir et al. 1981; Hambidge et al. 1983; Hunt et al. 1983; Campbell-Brown et al. 1985; Wolfe et al. 1994). Hair $\mathrm{Zn}$ concentrations represent a chronic index, reflecting $\mathrm{Zn}$ status during the preceding 4-8 weeks depending on the rate of hair growth and length of the hair shaft analysed (Gibson, 1990). Cutoff points for hair $\mathrm{Zn}$ values indicative of low $\mathrm{Zn}$ status during pregnancy have not been clearly defined. We used a cut-off value of $1.68 \mu \mathrm{mol} / \mathrm{g}$, a value applicable for the rainy season (i.e. winter) (Gibson et al. 1989a) and used in earlier studies of children because it has been associated with impaired function attributed to $\mathrm{Zn}$ deficiency (Gibson et al. 1989b; Cavan et al. 1993). To our knowledge, there are no other reported data on hair $\mathrm{Zn}$ concentrations of pregnant women living in developing countries.

In summary, the suggestion that $\mathrm{Zn}$ is a limiting nutrient in the diets of these rural pregnant Malawian women was supported by biochemical as well as dietary indices of $\mathrm{Zn}$ status. Dietary inadequacy was induced by maize-based diets high in phytate, a potent inhibitor of $\mathrm{Zn}$ absorption, and low intakes of flesh foods, a rich source of readily available $\mathrm{Zn}$. The precise impact of such a low maternal $\mathrm{Zn}$ status on pregnancy outcome in these rural Malawian women remains to be established.

\section{Acknowledgements}

This study was supported by the International Development Research Centre (IDRC) of Canada, Opportunities for Micronutrient Interventions (OMNI) Project, and the Natural Sciences and Engineering Research Council of Canada. J.-M. H. was a recipient of a Young Canadian Research Award from IDRC Canada. We thank the women who participated in the study, Mrs T. Cullinan, our Malawian research assistants Diane Muwa and Haclean Chapingasa, and the staff of the Jalasi Health Centre, TA Jalasi, for all their assistance.

\section{References}

Apgar J (1985) Zinc and reproduction. Annual Review of Nutrition 43, 43-68.

Apgar J (1992) Review: zinc and reproduction: an update. Journal of Nutritional Biochemistry 3, 266-278.

Arnaud J, Preziosi, P, Mashako L, Galan P, Nsibu C, Favier A, Kapongo C \& Hercberg S (1994) Serum trace elements in Zairian mothers and their newborns. European Journal of Clinical Nutrition 48, 341-348.

Bindra GS, Gibson RS \& Thompson LU (1986) [Phytate][calcium]/zinc ratios in Asian immigrant lacto-ovo vegetarian diets and their relationship to zinc nutriture. Nutrition Research 6 , 475-483.

Breskin MW, Worthington-Roberts BS, Knopp RH, Brown Z, Plovie B, Mottet NK \& Mills JL (1983) First trimester serum zinc concentrations in human pregnancy. American Journal of Clinical Nutrition 38, 943-953.

Brown KH, Lanata CF, Yuen ML, Peerson JM, Butron B \& Lonnerdal B (1993) Potential magnitude of the misclassification 
of a population's trace element status due to infection: an example from a survey of young Peruvian children. American Journal of Clinical Nutrition 58, 549-554.

Campbell-Brown M, Ward RJ, Haines AP, North WRS, Abraham R, McFadyen IR, Turnland JR \& King JC (1985) Zinc and copper in Asian pregnancies - is there evidence for a nutritional deficiency? British Journal of Obstetrics and Gynaecology 92 , 875-885.

Cavan KR, Gibson RS, Graziosos CF, Isalgue AM, Ruz M \& Solomons NW (1993) Growth and body composition of periurban Guatemalan children in relation to zinc status: a crosssectional study. American Journal of Clinical Nutrition 57, 334-343.

Davies NT, Carswell AJP \& Mills CF (1985) The effect of variation in dietary calcium intake on the phytate-zinc interaction in rats. In Trace Elements in Man and Animals, pp. 440-442 [CF Mills, I Bremner and JK Chesters, editors]. Slough: Commonwealth Agricultural Bureau.

Ferguson EL, Gadowsky SL, Huddle J-M, Cullinan TR, Lehrfeld J \& Gibson RS (1995) An interactive 24-h recall technique for assessing the adequacy of trace mineral intakes of rural Malawian women; its advantages and limitations. European Journal of Clinical Nutrition 49, 565-578.

Ferguson EL, Gibson RS, Thompson LU \& Ounpuu S (1989a) The dietary calcium, phytate, and zinc intakes, and the calcium, phytate and zinc molar ratios of a selected group of East African children. American Journal of Clinical Nutrition 50, 1450-1456.

Ferguson EL, Gibson RS, Thompson LU, Ounpuu S \& Berry M (1988) Phytate, zinc and calcium contents of 30 East African foods and their calculated phytate:zinc, $\mathrm{Ca}$ :phytate, and $[\mathrm{Ca}][$ phytate] $/[\mathrm{Zn}]$ molar ratios. Journal of Food Composition and Analysis 1, 316-325.

Ferguson EL, Gibson RS, Weaver SD, Heywood P, Heywood A \& Yaman C (1989b) The mineral content of commonly consumed Malawian and Papua New Guinean Foods. Journal of Food Composition and Analysis 2, 260-272.

Food and Agriculture Organization/World Health Organization/United Nations University (1985) Energy and Protein Requirements. WHO Technical Report Series no. 724. Geneva: WHO.

Frisancho AR (1990) Anthropometric Standards for the Assessment of Growth and Nutritional Status. Ann Arbor: The University of Michigan Press.

Gibson RS (1990) Principles of Nutritional Assessment. New York: Oxford University Press.

Gibson RS \& DeWolfe MS (1979) The zinc, copper, manganese, vanadium and iodine content of hair from 38 Canadian neonates. Pediatric Research 13, 959-962.

Gibson RS, Smit-Vanderkooy PD \& MacDonald AC (1989a) Seasonal variations in hair zinc concentrations in Canadian and African children. Science of the Total Environment 84, 291-298.

Gibson RS, Smit-Vanderkooy PD, MacDonald AC, Goldman A, Ryan BA \& Berry M (1989b) A growth-limiting mild zinc deficiency syndrome in some Southern Ontario boys with low height percentiles. American Journal of Clinical Nutrition 49, 1266-1277.

Goldenberg RL, Tamura T, Neggers Y, Copper RL, Johnston KE, DuBard MB \& Hauth JC (1995) The effect of zinc supplementation on pregnancy outcome. Journal of the American Medical Association 274, 463-468.

Hambidge KM \& Droegemueller W (1974) Changes in plasma and hair concentrations of zinc, copper, chromium, and manganese during pregnancy. Obstetrics and Gynecology 44, 666-672.

Hambidge KM, Krebs NF, Jacobs MA, Favier A, Guyette L \& Ilke DN (1983) Zinc nutritional status during pregnancy: a longitudinal study. American Journal of Clinical Nutrition 37, $429-442$.

Hunt IF, Murphy NJ, Cleaver AE, Farafi B, Swenseid ME, Coulson AH, Clark VA, Laine N, Davis CA \& Smith CJ (1983) Zinc supplementation during pregnancy: zinc concentration of serum and hair from low-income women of Mexican descent. American Joumal of Clinical Nutrition 37, 572-582.

Kirksey A, Wachs TD, Yunis F, Srinath U, Rahmanifar A, McCabe GP, Galal OM, Harrison GG \& Jerome NW (1994) Relation of maternal zinc nutriture to pregnancy outcome and infant development in an Egyptian village. American Journal of Clinical Nutrition 60, 782-792.

Kuhnert BR, Kuhnert PM, Lazebnik N \& Erhard P (1988) The effect of smoking on the relationship between maternal and fetal zinc status and infant birth weight. Journal of the American College of Nutrition 7, 309-316.

Kushner I (1993) Regulation of the acute phase response by cytokines. Perspectives in Biology and Medicine 36, 611-622.

Lockitch G (1993) Handbook of Diagnostic Biochemistry and Hematology in Normal Pregnancy. Ann Arbor: CRC Press.

Lohman TG, Roche AF \& Martorell R (editors) (1988) Anthropometric Standardization Reference Manual. Champaign, IL: Human Kinetic Books.

McMichael AJ, Dreosti IE, Gibson GT, Hartshorne JM, Buckley RA \& Colley DP (1982) A prospective study of maternal serum zinc levels and pregnancy outcome. Early Human Development 7, 59-69.

Mbofund CMF \& Atinmo T (1987) Trace element nutriture of Nigerians. World Review of Nutrition and Dietetics 51, 105139.

Merchant K, Martorell R \& Haas JD (1990a) Consequences for maternal nutrition of reproductive stress across consecutive pregnancies. American Journal of Clinical Nutrition 52, 616620.

Merchant K, Martorell R \& Haas JD (1990b) Maternal and fetal responses to the stresses of lactation concurrent with pregnancy and of short recuperative intervals. American Journal of Clinical Nutrition 52, 80-88.

Nagra SA, Jannat A, Farooqi MI \& Anwar J (1988) Hemoglobin, serum calcium, copper, magnesium and zinc during the first trimester of pregnancy in Pakistani women. Ecology of Food and Nutrition 22, 307-312.

National Statistical Office, Malawi (1994) Malawi Demographic and Health Survey 1992. Zomba, Malawi: National Statistical Office.

Oberleas D \& Harland BF (1981) Phytate content of foods: effect on dietary zinc bioavailability. Journal of the American Dietetic Association 79, 433-436.

Okonofua FE, Isinkaye A, Onwudiegwu U, Amole FA, Emofurieta WA \& Ugwu NC (1990) Plasma zinc and copper in pregnant Nigerian women at term and their newborn babies. International Journal of Gynaecology and Obstetrics 32, 243-245.

Sarram M, Younessi M, Kyorvash P, Kfoury GA \& Reinhold JG (1969) Zinc nutrition in human pregnancy in Fars province, Iran. American Journal of Clinical Nutrition 22, 726-732.

Scholl T, Hediger ML, Fischer RL \& Shearer JW (1992) Anemia vs iron deficiency: increased risk of preterm delivery in a prospective study. American Journal of Clinical Nutrition 55, 985-988.

Solomons NW (1981) Zinc and copper in human nutrition. In Nutrition in the 1980's: Constraints on our Knowledge. Progress in Clinical and Biological Research, vol. 67, pp. 97-127 [N Selvey and PL White, editors]. New York: Alan R. Liss.

Swanson CA \& King JC (1983) Reduced serum zinc concentration during pregnancy. Obstetrics and Gynecology 62, 313318. 
Swanson CA \& King JC (1987) Zinc and pregnancy outcome. American Journal of Clinical Nutrition 46, 763-771.

Tamura T \& Goldenberg RL (1996) Zinc nutriture and pregnancy outcome. Nutrition Research 16, 139-181.

Tuttle S, Aggett PJ, Campbell D \& MacGillivray I (1985) Zinc and copper nutrition in human pregnancy: a longitudinal study in normal primigravidae and in primigravidae at risk of delivering a growth retarded baby. American Journal of Clinical Nutrition 41, 1032-1041.

Valdes-Ramos R (1992) Zinc: a perinatal point of view. Progress in Food and Nutrition Science 16, 279-306.

Veillon C, Patterson KY \& Reamer DC (1985) Preparation of a bovine serum pool to be used for trace element analysis. In Biological Reference Materials, Availability, Uses, and Need for Validation of Nutrient Measurement, pp. 167-177 [WR Wolfe, editor]. New York: John Wiley \& Sons.

Vir SC, Love AHG \& Thompson W (1981) Zinc concentration in hair and serum of pregnant women in Belfast. American Journal of Clinical Nutrition 34, 2800-2807.

Watts DH, Krohn MA, Wener MH \& Eschenbach DA (1991) Creactive protein in normal pregnancy. Obstetrics and Gynecology 77, 176-180.

WHO (1996) Trace Elements in Human Nutrition and Health. Geneva: World Health Organization.

Wolfe SA, Gibson RS, Gadowsky SL \& O'Connor DL (1994) Zinc status of a group of pregnant adolescents at 36 weeks gestation living in Southern Ontario. Journal of the American College of Nutrition 13, 154-164. 